\title{
The mediation effect of burnout on the influence of role stressors towards lecturer performance: Empirical evidence from Indonesia
}

\author{
Lina \\ Department of Accountancy \\ University of Pelita Harapan, Indonesia
}

\section{Keywords}

Role Conflict, Role Ambiguity, Role Overload, Burnout, Lecturer Performance

\begin{abstract}
The objective of this study which focused on educational industry in Indonesia is to provide empirical evidence about the negative influence of role stressors on lecturer performance. Three major components of role stressors are role conflict, role ambiguity, and role overload. This study also examines burnout as the mediation of role stressors on lecturer performance. Primary data were obtained through distribution copies of questionnaire to the respondents. Eligible respondents were full time lecturers of faculty of economics at private universities in West Jakarta, Indonesia. Hypotheses test uses path analysis. Followings are the research results. Role conflict has no influence on lecturer performance. This result means that the incompatible tasks that have been given to the lecturers do not directly influence their performance. This research proves that role ambiguity and role overload have negative influence directly on lecturer performance. Lecturers need clear frameworks of their tasks.

This research successfully proves the mediation of burnout on the influence of three major components of role stressors on lecturer performance. The practical implication of this research is very useful for the management team in managing lecturers in private universities. Continuous new additional task as a form of role conflict will cause burnout and will ultimately has an impact on performance. Unclear role will be confusing to the lecturer and will cause burnout which at the end will create lower lecturer performance. Pressure of too many works to be done or too little time to do so many tasks will cause burnout which at the end will cause lower performance.
\end{abstract}

Corresponding author: Lina

Email addresses for corresponding author: lina.fe@uph.edu

First submission received: $11^{\text {th }}$ October 2017

Revised submission received: $2^{\text {th }}$ November 2017

Accepted: 28 th December 2017

\section{Introduction}

Kahn et al. (1964) have developed a theory of role dynamics which sees stress resulting from conflicting or incompatible expectations and unclear or vague expectations. Expectations which are in conflict may result in role conflict for the individual, while unclear or vague expectations may cause role ambiguity. Since role conflict and ambiguity pose problems of adjustment for the individual, Kahn et al. (1964) predicted and found lower levels of job satisfaction for those with high conflict and ambiguity. Role overload or workload is the third form of role stress and it can be defined as several tasks assigned to perform more than individual's capabilities, time pressures as well as scarcity of resources to fulfill commitment (Beehr \& Glazer, 2005).

According to Sing and Dubey (2011), role stressors have three major components which are role conflict, role ambiguity, and role overload. The following are the definition of role stressors component (Akgunduz, 2015). Role conflict occurs when employees are confronted with expectations for different roles, such as when two roles should be performed simultaneously or when performing one role prevents performing the other one. Role ambiguity occurs when there is an ambiguity in the role of a person in the organization or when the person does not know what to do or how to perform his or her role. Role overload increases when the fulfillment of a role becomes impossible for the individual because of time, energy or resources. 
Some previous research found that role stressors have influence on burnout. Murtiasri dan Ghozali (2006) found that role conflict, role ambiguity, and role overload have positive influence on auditor burnout. Jones et al. (2010) proved that role conflict has no effect on burnout. On the other hand, role ambiguity and role overload have positive influence on burnout. Utami and Nahartyo (2013) found different result. Role conflict and role overload have positive influence on burnout but cannot proved the positive influence of role ambiguity on burnout.

Burnout is defined as a negative psychological experience that is the reactions to job-related stress. It pertains to feelings experienced by people whose jobs require repeated exposure to emotionally charged social situations. Thus, it is an occupational hazard to which all members of helping professions are exposed, including teachers (Goswami, 2013). There is a general view that teacher burnout may have a negative impact on the teachers themselves leading, for instance, to emotional and physical ill-health, and on the students as burned out teachers may be relatively impaired in the quality of teaching and commitment, may give less information and less praise as well as interact less with students. (Salami, 2011). Teaching is among the most stressful jobs in the world. Teachers experience a lot of stress due to the nature of their profession (Shamsafrouz, 2015). Teaching can be considered a high-stress occupation. An education system has all the elements associated with stress such as a bureaucratic structure, continuous evaluation of its processes and outcomes, and increasingly intensive interpersonal interactions with students, parents, colleagues, principals and the community etc. In addition, increased student misconduct, student apathy, overcrowded classrooms, inadequate salaries, demanding or unsupportive parents, budgetary constraints, expanding administrative loads, lack of infrastructural support, and an increasingly negative public opinion have contributed to an embittered teacher force throughout the world. Lecturers who suffer burnout are in lower levels of job satisfaction which cause reduction in their motivation and performance (Goswami, 2013). Performance involves a quality and quantity of outcomes from individual or group effort attainment. Job performance is the amount of effort an individual will exert in his or her job. Moreover, the real meaning of job performance relies on the beliefs in the organization about which behaviors are most valued and the demands of the job, the goals and missions of the organization (Rizwan et al., 2014).

Research conducted by Murtiasri and Ghozali (2006) develop burnout as a key mediator for role stressors (role conflict, role ambiguity and role overload) on critical job outcomes (job satisfaction, turnover intention and job performance). The research successfully proved burnout as a mediator for role stressors on job performance. Other research conducted by Celik (2013) investigates the effects on role stressors on performance by using burnout as mediating variable. This research only uses role ambiguity and role conflict as components of role stressors. The result showed that indirect and direct effect of role ambiguity and role conflict was proved. However, there is lack of research focused on the role stressors on lecturer performance in higher education by using burnout as a mediator. So, it is clearly necessary to conduct more studies to investigate that topic.

This study aims to provide empirical evidence about the negative influence of role stressors on lecturer performance. Role stressors consist of role conflict, role ambiguity, and role overload. Besides test the direct influence, this study also examines the indirect influence of role stressors on lecturer performance through mediation of burnout. The focus of this research is on educational industry. Studying burnout among the lecturers has implications for improving understanding of job stress and burnout as well as for enhancing their working life. Understanding environmental and personal influences on burnout may give several benefits for universities and lecturers to improve their quality. It is hoped that this study will contribute to expand research topic on role stressors and provide opportunities for researchers to observe the influences of role stressors on lecturer performance by considering burnout as mediator. The next section contains a review of the relevant literature and development of research hypotheses. Methods, data, and analysis of research result are presented and discussed in the following section. The last section provides conclusions.

\section{Literature Review and Hypotheses Development}

\subsection{Role Stressors}

Hitt et al. (2015) defines role stressors as environmental conditions that cause individuals to experience stress. Organizational and work-related causes of stress include role conflict, role ambiguity, 
work overload. All of us have many roles. Many times, these roles are reasonably compatible. Sometimes, however, they are not compatible and create conflicting demands and requirements. This situation, known as role conflict, has been demonstrated to be a significant work stressor and is often associated with dissatisfaction, tardiness, absenteeism, and turnover. Role ambiguity refers to the situation in which jobholders are unclear about the goals, expectations, or requirements of their jobs. Under ambiguous job demands, people are unsure of what is expected of them and how they will be evaluated. Several management jobs have high role ambiguity; thus, ambiguity is another contributor to the high stress often experienced in managerial jobs. Ambiguity on the job creates tension and anxiety. Reaction to this stress is likely to be emotional. Moreover, role ambiguity has been shown to have strong negative effects on job motivation and performance, even stronger than role conflict in many instances. Further, it often has stronger effects on tardiness, absenteeism, and turnover than does role conflict. Another common cause of stress in organizations is work overload. Overload can be quantitative (too much work) or qualitative (work is too complex). Research suggests that qualitative overload creates more stress than quantitative overload.

\subsection{Burnout}

Psychological responses to stress include anxiety, depression, low self-esteem, sleeplessness, frustration, family problems, and burnout (Hitt et al., 2015). Some of these psychological reactions are more severe than others. One important psychological problem is burnout. Burnout was first defined by Freudenberger (1974) and involves feelings of failure and exhaustion resulting from excessive demands on a person's energy with insufficient reward for the effort. Associates and managers experiencing burnout show little or no enthusiasm for their jobs and generally experience constant fatigue (Hitt et al., 2015). These individuals often complain bitterly about their work, blame others for mistakes, are absent from work more and more often, are uncooperative with co-workers, and become increasingly isolated. Burnout often occurs in jobs that require individuals to work closely and intensely with others under emotionally charged conditions.

\subsection{Performance}

Job performance is a measure of efficiency and effectiveness of work achievement, defined as an evaluation of work done through direct superior, co-workers, self and direct subordinates (Kalbers \& Fogarty, 1995). Job performance also refers to the behaviors of employees involved in certain jobs, including their effectiveness and the outcomes of these behaviors (Babin and Boles, 1998).

\subsection{Role Conflict and Performance}

The main purpose of the study conducted by Akgunduz (2015) is to explore the influence of self-esteem and role stress on job performance in the hotel businesses. Moreover, the research aims to discover which role stress factors, i.e. role ambiguity, role conflict and role overload, have the most detrimental effect on an employee's role stress in the hotel businesses. The outcome of the study indicated that role conflict is negatively associated with job performance. Afifah et al. (2015) examine the influence of role conflict, self- efficacy, and professional ethical sensitivity to auditor performance with emotional quotient as moderating variable. Respondents in this study are auditors who work for public accounting firms in Pekanbaru, Batam, and Medan, Indonesia. The samples in this study are 145 auditors from 29 public accounting firms. The result shows that role conflict negatively and significantly affects auditor performance. Research conducted by Apsari and Setiawan (2014) found that role conflict has negative significant influence on employee performance. Celik (2013) shows the direct effect of role conflict on performance. Nur et al. (2016) examine the influence of role conflict, role ambiguity and job stress on the employee's performance at PT Midi Utama Indonesia Tbk, Samarinda. Research sample consists of 40 respondents. This research proved that role conflict affects employee performance negatively. Khuong and Yen (2016) also proved that role overload has negative influence on job performance. The purpose of research conducted by Agustina (2009) was to analyze and examine the effect of role conflict, role ambiguity, and role overload on job satisfaction and job performance of junior auditor who work at Public Accounting Firm that has cooperation with big four Public Accounting Firms in DKI Jakarta. The result indicates that role conflict has negative influence on job performance. Sari and Suryanawa (2016) conducted a study to determine the effect of role conflict, role ambiguity, 
and role overload on the performance of auditors with time pressure as a moderation variable. Based on the test results, it can be proved that role conflict has a negative effect on auditor performance. Ermawati et al (2014) examine the effect of role stressor on auditor performance by using emotional quotient as moderating variable. Role stressors consist of role conflict and role ambiguity. The result shows that role conflict has significant influence on auditor performance. This result was consistent with Murtiasri and Ghozali (2006). Gunawan and Ramdan (2012) determine and obtain empirical evidence on the factors related to the behavior of auditors that could affect the performance of auditors who work in Public Accounting Firm (KAP), Jakarta. This research discusses the factors regarding role conflict, role ambiguity, role excess, and leadership style. One hundred sixty-eight samples were used in this study. The results of this study indicate that role conflict does not significantly affect the performance of the auditor. Research conducted by Rizwan et al. (2014) shows consistent result. There is no significant relationship between role conflict and job performance.

$\mathrm{H}_{1}$ Role conflict has negative influence on lecturer performance.

\subsection{Role Ambiguity and Performance}

Ermawati et al. (2014) took the research location in 8 Public Accounting Firms that located in Bali. Research sample consist of 69 auditors. This research proved that role ambiguity has significant influence on auditor performance. Murtiasri and Ghozali (2006) also found that role ambiguity has direct influence on auditor performance. Apsari and Setiawan (2014) found that role ambiguity has negative significant influence on employee performance. The direct effect of role ambiguity on performance has found by Celik (2013). Nur et al. (2016) found that role ambiguity has negative influence on employee performance. Gunawan and Ramdan (2012) also found that role ambiguity has significant influence on the performance of auditors. This result was consistent with Agustina (2009). Role ambiguity has negative effect on auditor performance can be proved through research conducted by Sari and Suryanawa (2016). Role ambiguity will cause uncomfortable feeling and tension in work so that will degrade the performance of auditor. Akgunduz (2015) was used questionnaires and the participants were drawn from 227 hotel employees in Kusadasi, Turkey. The result shows that role ambiguity is negatively associated with job performance. Role ambiguity creates more role stress than role conflict. Khuong and Yen (2016) also proved that role ambiguity has negative influence on job performance. To achieve the pleasures of successful work place is an art of coping with stress. Job stress is a very important issue in this new era. So, Rizwan et al. (2014) emphasized the root causes of job stress like role conflict, role ambiguity, and identifies its effects on job satisfaction and job performance. From several organizations, a self-administered questionnaire was used for data collection. Two-hundred questionnaires were distributed out of which 150 were chosen for more study and suitable sampling method was used for this. The results show that there is no significant relation of role ambiguity and job performance.

$\mathrm{H}_{2}$ Role ambiguity has negative influence on lecturer performance.

\subsection{Role Overload and Performance}

Khuong and Yen (2016) analyzed the effects of five working factors including work overload, role ambiguity and role conflict, working relationship, career development, and working environment on job stress and on job performance in six different industries at Dong Xuyen Industrial Zone, Ba Ria Vung Tau province, Vietnam. To collect the primary data, questionnaire was directly sent to 378 respondents. Quantitative approach was the major method used. As a result, these working factors had negative influence on job performance. Agustina (2009) concluded that role overload negatively affects the performance of junior auditors. Sari and Suryanawa (2016) proved that role overload has negative influence on auditor performance. Auditors generally face role overload when peak season. If the auditor is unable to complete the job well in accordance with the given time limit, then it indicates that the auditor's performance decreased. Research conducted by Akgunduz (2015) shows the different result that role overload is positively associated with job performance. Murtiasri and Ghozali (2006) found that role overload has no direct influence on job performance. Gunawan and Ramdan (2012) also found that role overload has no effect on the performance of auditors.

$\mathrm{H}_{3}$ Role overload has negative influence on lecturer performance. 


\subsection{Role Stressors, Burnout, and Performance}

The objective of study conducted by Murtiasri and Ghozali (2006) is to develop burnout construct in accounting occupation by showing that burnout is a key mediator for role stressors (role conflict, role ambiguity and role overload) on critical job outcomes (job satisfaction, turnover intention and job performance). The result revealed that role conflict, role ambiguity, and role overload have indirect effect on job performance through mediation of burnout. Celik (2013) conducted research on two hundred vice principals at elementary and high schools in the city centers of Denizli and Manisa. This study investigates the effects on role ambiguity and role conflict by using burnout as mediating variable. The indirect and direct effect of role ambiguity and role conflict were found.

$\mathrm{H}_{4}$ Role conflict has negative influence on lecturer performance through the mediation of burnout. $\mathrm{H}_{5}$ Role ambiguity has negative influence on lecturer performance through the mediation of burnout. $\mathrm{H}_{6}$ Role overload has negative influence on lecturer performance through the mediation of burnout.

\section{Research Method}

\subsection{Population}

The population is a complete group of elements which are generally people, objects, transactions, or events in which we are interested in studying or becoming the object of research (Kuncoro, 2009). Population in this research is lecturers at universities in West Jakarta area, Indonesia.

\subsection{Sample}

Sampling technique is non probability sampling by using purposive sampling method. The criteria specified are full time lecturers of Faculty of Economics at private universities due to ease of access. In relation to the variables studied, namely role stressors, burnout, and performance, this study was not conducted at the university level because the level of role stressors and burnout will be different among faculty so that this research only focuses on the faculty of economics. There is a difference in workload between full time lecturers and part time lecturers. Full time lecturers in Indonesia have the responsibility to carry out teaching, research, and community service as well as acting as an academic advisor, thesis supervisor, student activity assistant, and other administrative duties as well. This difference in workload results in performance differences being measured. This is why this research has a focus on full time lecturers. In Indonesia, there are two forms of university ownership which are state universities and private universities. Both forms of the university have differences in policy, leadership style, management philosophy, and other factors. On the basis of this, the study chose private universities.

\subsection{Research Data}

This research uses primary data that have collected through sending 150 copies of questionnaire to the respondents. These are the total of potential respondents who meet the criteria. Accepted questionnaires was 126 ( $84 \%$ response rate). Three questionnaires were drop because there were incomplete responses. Finally, there were 123 eligible questionnaires for analysis. Here is the questionnaire summary.

\begin{tabular}{cc}
\hline Description & Amount \\
\hline Distributed copies of questionnaire & 150 \\
\hline Accepted copies of questionnaire & 126 \\
Incomplete copies of questionnaire & $\frac{(3)}{123}$ \\
Used copies of questionnaire & 126 \\
\hline
\end{tabular}

Table 1. Questionnaire Summary

The following are demographic of respondents.

\begin{tabular}{cc}
\hline Demographic & Number and percentage \\
\hline Number of respondent & 123 \\
AGE & \\
Minimum & 29.00 \\
Maximum & 77.00 \\
Mean & 44.30 \\
Deviation Standard & 10.50 \\
\hline
\end{tabular}

\section{GENDER}




\begin{tabular}{cc} 
Male & $58(47.15 \%)$ \\
Female & $65(52.85 \%)$ \\
\hline S1 & $7(5.69 \%)$ \\
S2 & $99(80.49 \%)$ \\
S3 & $17(13.82 \%)$ \\
\hline PROGRAM & $65(52.85 \%)$ \\
Undergraduate - Management & $58(47.15 \%)$ \\
\hline Undergraduate - Accounting &
\end{tabular}

Table 2. Demographic of Respondents

Respondents consist of 58 male $(47.15 \%)$ and 65 female $(52.85 \%)$. Their age range is $29-77$. Majority of the respondents have master degree education level (80.49\%). Respondents from management program amounted to 65 and the rest from accounting program.

\subsection{Data Analysis Technique}

To give the empirical evidence, this research uses quantitative method. Primary data was used in this study that obtained through distribution of questionnaires. This research conduct data quality test which are consist of validity test and reliability test. A questionnaire considered valid if the questions in the questionnaire were able to reveal something that will be measured by the questionnaire (Ghozali, 2015). Validity test used bivariate correlation which is Pearson correlation coefficients. Reliability is actually a tool to measure a questionnaire which is an indicator of variables or constructs. A questionnaire said to be reliable if someone answers the statement is consistent or stable over time (Ghozali, 2015). A construct or a variable value said to be reliable if the Cronbach alpha $>0.60-0.80$ (Hair et al., 2014). To test the hypothesis, this research uses path analysis. Path analysis allows us to test the direct relationship between variables and indirect relationships among variables in the model (Latan and Ghozali, 2012).

\subsection{Operational Variables}

The independent variables of this study are role conflict, role ambiguity, and role overload. The instruments developed by Rizzo, House, and Lirtman (1970) and modified by Murtiasri and Ghozali (2006) to measure role conflict. The instrument consists of 5 items for role conflict Respondents can choose a 5-point likert scale. The questionnaire tries to get information: 1). the respondents do not have freedom to perform tasks other than the manner prescribed by the superiors, 2). the respondents received assignment without sufficient resources and materials to complete it, 3 ). the respondents must put aside the rules or policies that unsuitable for support task completion, 4). the respondents' work not necessarily be accepted by all party's concern because of the differences of their work style, 5). the respondents must work on tasks that are not in accordance with the competencies of him/her self.

To measure role ambiguity, this study used the instruments developed by Rizzo, House, and Lirtman (1970) and modified by Murtiasri and Ghozali (2006). The instrument consists of 5 items on 5point likert scale. For role ambiguity, the questionnaire will get information: 1 ). the respondents do not have clear authority in the organization, 2). the respondents do not have clear work objective in the organization, 3). the respondents do not understand the scope of responsibility in their position in the organization, 4). the respondents do not understand clearly the expectations of this organization on their capability. 5). the respondents do not get information regarding their work in the organization.

Role overload was measured using instrument developed by Beehr, Walsh and Taber (1976) and modified by Murtiasri and Ghozali (2006). The instrument consists of 3 items on 5-point likert scale to know whether the respondents: 1). have enough time to finish their work in accordance with the expectations of the organization, 2). feel that the work was burdening too much, 3). have difficulty to meet the too high-performance standards in their organization.

Burnout is intervening/mediator variable. The instrument developed by Maslach and Jackson (1981). Each respondent was asked to rate the level of burnout by giving response to 8 statements. Respondents chose a 5-point likert scale to get information from the respondents whether: 1). they feel emotionally drained because of the job. 2). they feel tired at the end of the working day. 3). they feel 
tired because of the job. 4). they deal very effectively with problems faced by the students. 5). they can easily understand their students to various issues. 6). they feel that they treat the students as unimportant "objects". 7). they have no feeling toward others anymore. 8). they worried that this work has hardened their heart emotionally.

Lecturer performance is dependent varieble. Lecturer performance was measured using instrument developed by Fisher (2001). This instrument consists of 10 items on 5-point likert scale to know whether the respondents able to: 1). maintain the quantity of work. 1). maintain the quality of work. 3). communicate orally. 4). Communicate in writing. 5). responsible for their job. 6). increase their professional skills. 7). follow the policy and procedure that have been set up. 8). make job planning. 9). adapt to the new task. 10). cooperate with others in organization.

\section{Discussions and Conclusions}

\subsection{Validity Test}

This research uses Pearson correlation test to get the $r$ count. This $r$ count will compare to $r$ table with significance level at $5 \%$ and degree of freedom $=n-2=123-2=121$. The value of $r$ table for this level is 0.177 . According to table 3 , all statements are valid because $r$ count is greater than $r$ table.

\begin{tabular}{lcc}
\hline \multicolumn{1}{c}{ Variable } & Correlation Range & Description \\
\hline Role Conflict & $0.508-0.746$ & Valid \\
Role Ambiguity & $0.756-0.857$ & Valid \\
Role Overload & $0.803-0.877$ & Valid \\
Burnout & $0.265-0.783$ & Valid \\
Employee Performance & $0.522-0.819$ & Valid \\
\hline
\end{tabular}

Table 3. Validity Test Result

\subsection{Reliability Test}

Reliability test result of all variables can be seen in table below. According to table 4, all statements in the questionnaires have high consistency.

\begin{tabular}{|c|c|c|}
\hline Variable & Cronbach's Alpha & Description \\
\hline Role Conflict & 0.760 & Reliable \\
\hline Role Ambiguity & 0.808 & Reliable \\
\hline Role Overload & 0.842 & Reliable \\
\hline Burnout & 0.739 & Reliable \\
\hline Employee Performance & 0.769 & Reliable \\
\hline
\end{tabular}

\subsection{Hypothesis Test}

Table 4. Reliability Test Result

\begin{tabular}{lccc}
\hline \multicolumn{1}{c}{ Hypothesis } & Significance Value & $\begin{array}{c}\text { Unstandardized } \\
\text { Coefficient }\end{array}$ & Result \\
\hline $\mathrm{H}_{1}$ : Role Conflict $\rightarrow$ Employee Performance & $0.088^{*}$ & -0.154 & $\mathrm{H}_{1}$ not supported \\
$\mathrm{H}_{2}$ : Role Ambiguity $\rightarrow$ Employee Performance & $0.003^{*}$ & -0.220 & $\mathrm{H}_{2}$ supported \\
$\mathrm{H}_{3}$ : Role Overload $\rightarrow$ Employee Performance & $0.001^{*}$ & -0.222 & $\mathrm{H}_{3}$ supported \\
\hline
\end{tabular}

\begin{tabular}{llll}
\hline & \multicolumn{1}{c}{ Standardized Beta } & Result \\
\hline Role Conflict $\rightarrow$ Burnout & 0.191 & Direct Effect & \\
Burnout $\rightarrow$ Employee Performance & 0.021 & Direct Effect
\end{tabular}




\begin{tabular}{|c|c|c|c|}
\hline Role Conflict $\rightarrow$ Employee Performance & -0.155 & Direct Effect & \\
\hline $\mathrm{H}_{4}$ : Role Conflict $\rightarrow$ Burnout $\rightarrow$ Employee Performance & 0.004 & Indirect Effect & $\mathrm{H}_{4}$ supported \\
\hline Role Ambiguity $\rightarrow$ Burnout & 0.200 & Direct Effect & \\
\hline Burnout $\rightarrow$ Employee Performance & 0.021 & Direct Effect & \\
\hline Role Ambiguity $\rightarrow$ Employee Performance & -0.264 & Direct Effect & \\
\hline $\mathrm{H}_{5}$ : Role Ambiguity $\rightarrow$ Burnout $\rightarrow$ Employee Performance & 0.004 & Indirect Effect & $\mathrm{H}_{5}$ supported \\
\hline Role Overload $\rightarrow$ Burnout & 0.478 & Direct Effect & \\
\hline Burnout $\rightarrow$ Employee Performance & 0.021 & Direct Effect & \\
\hline Role Overload $\rightarrow$ Employee Performance & -0.285 & Direct Effect & \\
\hline $\mathrm{H}_{6}:$ Role Overload $\rightarrow$ Burnout $\rightarrow$ Employee Performance & 0.010 & Indirect Effect & $\mathrm{H}_{6}$ supported \\
\hline
\end{tabular}

The symbols * represent the degree of significance at level $a=0.05$.

Table 5. Hypothesis Test Result

From table 5 above, hypothesis 1 is not supported because the significant value is 0.271 which is greater than 0.05 . Hypothesis 2 is supported since the significant value is 0.014 which is lower than 0.05 and with unstandardized coefficients is 0.166 means that leader behavior has positive influence on managerial performance. The indirect effect of reward on managerial performance through the mediation of organizational commitment is not supported since the standardized beta of direct effect of reward on managerial performance is 0.121 which is bigger than its indirect effect that has the standardized beta value of 0.081 . The same result occurs on the effect of leader behavior on managerial performance through the mediation of organizational commitment. It is not supported since the standardized beta of direct effect of leader behavior on managerial performance is 0.266 which is bigger than its indirect effect that has the standardized beta value of 0.065 .

Hypothesis 1 is not supported. The result shows that role conflict has no influence on lecturer performance. As a lecturer, we have many roles. Lecturers in Indonesia must meet the demands of Tri Dharma Perguruan Tinggi which has been established by the government, which is implementing teaching, research, and community service. In addition, the lecturer also runs several other roles such as acting as an academic advisor, supervisor and final assignment examiner, head of study group, lecture coordinator, may also be appointed as structural officer, conference chairman or supervisor of competition team. If the lecturer feels that some of the roles are still compatible, then the role conflicts will not appear. Role conflicts arise when lecturers feel that the additional new tasks that have been given to them are not compatible with their daily main role. Based on existing sample and results, role conflict has no direct influence on lecturer performance. It means additional new tasks do not affect their performance. This result is consistent with Gunawan \& Ramdan (2012) and with Rizwan et al (2014) but shows the opposite result with Akgunduz (2015), Afifah et al (2015), Apsari \& Setiawan (2014), Celik (2013), Nur et al (2016), Agustina (2009), Sari \& Suryanawa (2016), Ermawati (2014), Murtiasri \& Ghozali (2006), and with Khuong \& Yen (2016).

This research successfully supports second hypothesis. It means that role ambiguity directly has negative influence on lecturer performance. Role ambiguity causes confusion in completing the job. The condition of role ambiguity results when people not understanding what is expected from them and how the results of the work will be evaluated. As a lecturer, maybe we will receive certain assignments. If the leader does not provide clear direction, a role ambiguity may arise. To make sure that the university or the faculty can run smoothly, those conditions should be avoided by the management. Role ambiguity causes inconvenience in performing the given task so that the result of work becomes not optimal. The higher role ambiguity, the lower lecturer performance is. This result is consistent with Akgunduz (2015), Apsari \& Setiawan (2014), Celik (2013), Nur et al (2016), Gunawan \& Ramdan (2012), Agustina (2009), Sari \& Suryanawa (2016), Ermawati (2014), Murtiasri \& Ghozali (2006), and with Khuong \& Yen (2016) but shows the opposite result with Rizwan et al (2014).

Hypothesis 3 was supported. It means that the direct negative influence of role overload on lecturer performance has been proven. The higher the role overload, the lower the performance. Role overload is the condition when the lecturers do not have enough time and resources to finish their work 
in accordance with the expectations of the organization. Too high the performance standards in the organization will burden the lecturers that at the end will decrease their performance. As a lecturer, much work needs to be done such as carrying out teaching, research, community service and other tasks. In connection with these conditions, often feel lack of resources, especially time and energy to complete these tasks and responsibilities. Under lack of resources condition such as lack of time with so much work to do will make a person finish the tasks in careless way. They will ignore the quality of their performance. This result is consistent with Agustina (2009), Sari \& Suryanawa (2016), and with Khuong \& Yen (2016) but shows the opposite result with Akgunduz (2015), Gunawan \& Ramdan (2012), and with Murtiasri \& Ghozali (2006).

The result revealed that role conflict has negative influence on lecturer performance through burnout mediation. It means that this research has evidence to support fourth hypothesis. Burnout is a condition of physical, mental, and emotional exhaustion. Burnout does not happen instantaneously. In general, burnout is produced through long-term stress conditions. When a person experiences burnout, he can no longer perform his duties and responsibilities well. In this research sample it can be proven that continuous new additional task as a form of role conflict given to the lecturer, will eventually cause burnout. The burnout condition has a negative effect on performance. This result is consistent with the research conducted by Celik (2013) and Murtiasri \& Ghozali (2006).

Fifth hypothesis is role ambiguity has negative influence on lecturer performance through mediation of burnout. This research proved the mediation of burnout. Role ambiguity contributes to creating stress on work. A protracted stress will cause burnout. A person experiencing burnout, can no longer afford to work optimally because it no longer has an interest in his work. Unclear role will be confusing to the lecturer and will cause burnout which at the end will create lower lecturer performance. This result is consistent Celik (2013) and Murtiasri \& Ghozali (2006).

This research proved that role overload has negative influence on managerial performance through burnout mediation. Hypothesis 6 was also supported. Role overload can trigger burnout. Pressure of too many works to be done or too little time to do so many tasks will cause burnout. The result shows that role overload will cause burnout which at the end will cause lower performance. This result is consistent with Murtiasri \& Ghozali (2006).

\section{Research Limitations and Direction for Further Research}

The copy of questionnaires has not been spread evenly throughout Indonesia. It is expected that the future research will show different result if the distribution of the questionnaire can be expanded to as many as possible private universities throughout Indonesia.

\section{References}

Afifah, U., R.N. Sari, R. Anugerah, and ZM. Sanusi. (2015). the effect of role conflict, self- efficacy, professional ethical sensitivity on auditor performance with emotional quotient as moderating variable". Procedia Economics and Finance 31: 206-212.

Agustina, L. (2009). Pengaruh konflik peran, ketidakjelasan peran, dan kelebihan peran terhadap kepuasan kerja dan kinerja auditor. Jurnal Akuntansi, 1 (1): 40-69.

Akgunduz, Y. (2015). The influence of self-esteem and role stress on job performance in hotel businesses. International Journal of Contemporary Hospitality Management 27 (6): 1082-1099.

Apsari, M. and IA. Setiawan. (2014). Pengaruh role conflict dan role ambiguity terhadap kinerja karyawan. Jurnal Sains Manajemen dan Akuntansi 6 (1): 46-56.

Babin BJ. and JS. Boles. (1998). Employee behavior in a service environment: A model and test of potential differences between men and women. Journal of Marketing 62 (2): 77 - 91.

Beehr, T., J. Welsh, and T. Taber. (1976). Relationship of stress to individually and organizationally valued states: Higher order needs as moderator. Journal Applied Psychology 61: 41-47.

Beehr, T. A., \& S. Glazer. (2005). Organizational Role Stress. In J. Barling, K. Kelloway, \& M. Frone (Eds.). Handbook of Work Stress (7-33). Thousand Oaks, CA: Sage.

Celik, K. (2013). The effect of role ambiguity and role conflict on performance of vice principals: The mediating role of burnout. Eurasian Journal of Educational Research 51: 195-214.

Ermawati, MD., NK. Sinarwati, and E. Sujana. (2014). Pengaruh role stress terhadap kinerja auditor dengan emotional quotient sebagai variabel moderating. e-Journal Universitas Pendidikan Ganesha, 2 (1). 
Fisher, RT. (2001). Role stress, the type A behavior pattern, and external auditor job satisfaction and performance. Behavioral Research in Accounting 13 (1): 143-170.

Freudenberger, H. J. (1974). Staff burnout. Journal of Social Issues 30 (1): 159-165.

Ghozali, I. (2015). Aplikasi Analisis Multivariate Dengan Program IBM SPSS 23. Edisi 8. Semarang: Badan Penerbit Universitas Diponegoro.

Goswami, M. (2013). A study of burnout of secondary school teachers in relation to their job satisfaction. IOSR Journal of Humanities and Social Science 10 (1): 18-26.

Gunawan, H. and Z. Ramdan. (2012). Pengaruh konflik peran, ketidakjelasan peran, kelebihan peran, dan gaya kepemimpinan terhadap kinerja auditor di kantor akuntan publik wilayah DKI Jakarta. Binus Business Review 3 (2): 825-839.

Hair, JF., WC. Black, BJ. Babin, and RE. Anderson. (2014). Multivariate Data Analysis. 7th Ed. Pearson.

Hitt, MA., CC. Miller, and A. Colella. (2015). Organizational Behavior. $4^{\text {th }}$ Ed. John Wiley \& Sons.

Jones, A., CS. Norman, and B. Wier. (2010). Healthy lifestyle as a coping mechanism for role stress in public accounting. Behavioral Research in Accounting 22 (1): 21-41.

Kahn, RL., DM. Wolfe, RP. Quinn, JD. Snoek, and RA. Rosenthal. (1964). Organizational Stress: Studies in Role Conflict and Ambiguity. New York: Wiley.

Kalbers and T. Fogarty. (1996). Internal auditor profesionalism: An empirical analysis of its nature and its consequences. Auditing: A Journal of Practice and Theory 14 (1): 64-86.

Khuong, MN. and VH. Yen. (2016). Investigate the effects of job stress on employee job performance - A case study at Dong Xuyen Industrial Zone, Vietnam. International Journal of Trade, Economics and Finance 7 (2): 31-37.

Kuncoro, Mudrajad. (2009). Metode Riset untuk Bisnis dan Ekonomi. Jakarta: Erlangga.

Latan, H. and I. Ghozali (2012). Partial Least Squares Konsep, Teknik dan Aplikasi Menggunakan Program Smartpls 2.0 M3. Badan Penerbit Universitas Diponegoro.

Macslah, C and S. Jackson. (1981). Burnout in Organizational Settings. Applied Social Psychology Annual 5: 133-153.

Murtiasri, E. and I. Ghozali. (2006). Anteseden dan konsekuensi burnout pada auditor: Pengembangan terhadap role stress model. Simposium Nasional Akuntansi IX. Padang.

Nur, IR., T. Hidayati, and S. Maria. (2016). Pengaruh konflik peran, ambiguitas peran, dan stres kerja terhadap kinerja karyawan. Jurnal Manajemen 8 (1): 1-18.

Rizwan, M., A. Waseem, and SA. Bukhari. (2014). Antecedents of job stress and its impact on job performance and job satisfaction. International Journal of Learning E Development 4 (2): 187-203.

Rizzo, JR, RJ. House, and SI. Lirtzman. (1970). Role conflict and ambiguity in complex organization. Administrative Science Quartely 15: 150-163.

Salami, SO. (2011). Job stress and burnout among lecturers: Personality and social support as moderators. Asian Social Science 7 (5): 110-121.

Sari, NPER. and IK Suryanawa. (2016). Konflik peran, ketidakjelasan peran, dan kelebihan peran terhadap kinerja auditor dengan tekanan waktu sebagai pemoderasi. e-Jurnal Akuntansi Universitas Udayana 15 (2): $1392-1421$.

Shamsafrouz, H. and H. Haghverdi. (2015). The effect of burnout on teaching performance of male and female EFL teachers in L2 context. International Journal of Foreign Language Teaching $\mathcal{E}$ Research 3 (11): 47-58.

Singh, A.P. and A.K. Dubey. (2011). Role of stress and locus of control in job satisfaction among middle managers. The IUP Journal of Organizational Behavior 10 (1): 42-56.

Utami, I. and E. Nahartyo. (2013). The effect of type A personality on auditor burnout: Evidence from Indonesia. Accounting and Taxation 5 (2): 89-102. 